VIII-1 | 2016

Dewey's Democracy and Education as a Source of and a Resource for European Educational Theory and Practice

\title{
Dewey's Ancestry, Dewey's Legacy, and The Aims of Education in Democracy and Education
}

Avi I. Mintz

\section{(2) OpenEdition}

\section{Journals}

Electronic version

URL: http://journals.openedition.org/ejpap/437

DOI: 10.4000/ejpap.437

ISSN: 2036-4091

\section{Publisher}

Associazione Pragma

\section{Electronic reference}

Avi I. Mintz, "Dewey's Ancestry, Dewey's Legacy, and The Aims of Education in Democracy and

Education », European Journal of Pragmatism and American Philosophy [Online], VIII-1 | 2016, Online since 20 July 2016, connection on 20 April 2019. URL : http://journals.openedition.org/ejpap/437 ; DOI : 10.4000/ejpap.437

This text was automatically generated on 20 April 2019.

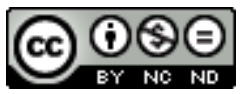

Author retains copyright and grants the European Journal of Pragmatism and American Philosophy right of first publication with the work simultaneously licensed under a Creative Commons AttributionNonCommercial-NoDerivatives 4.0 International License. 


\title{
Dewey's Ancestry, Dewey's Legacy, and The Aims of Education in Democracy and Education
}

\author{
Avi I. Mintz
}

\section{AUTHOR'S NOTE}

I am indebted to Deron Boyles and Len Waks for providing me with valuable feedback on an earlier draft of this paper.

\section{Introduction}

Democracy and Education was an ambitious project. Dewey stated in both 1916 and 1930 that it was the most comprehensive statement of his philosophy, ${ }^{1}$ but the work achieved something even greater: it put Dewey's name alongside the greatest Western philosophers who addressed education. Indeed, when Democracy and Education was published in 1916, it was hailed as the greatest work of educational philosophy since Rousseau's Emile (Cremin 1964: 120). By 1916, Dewey had already secured an international reputation as the greatest educational philosopher of his day. Thus his readers may have been inclined to receive his most comprehensive work on the philosophy of education as a landmark work on the topic. Perhaps his early readers drew this conclusion because at the heart of Democracy and Education is a chapter on "The Democratic Conception of Education" in which Dewey presented a positive statement of the relationship of democracy and education followed by a critique of Plato, Rousseau, and Fichte and Hegel. Dewey seemed to invite his readers to reflect on how his arguments stand next to theirs.

Did Dewey simply believe that critiquing historical philosophical conceptions of education would best help clarify his own account? Or might Dewey have had other motivations as well? Consideration of these questions, I argue, suggests an answer to 
another question, one that has persisted since the Dewey began writing on education: Why was Dewey so frequently misread? The answer to the former question is only partly that Dewey thought that there was value in tackling entrenched and influential educational ideas, and that doing so helped elucidate his own views. I argue that Dewey's discussion of educational aims was designed not only to critique Plato and Rousseau, but also primarily, subtly, and by analogy, to critique his American contemporaries via historical European philosophers. Recognizing Dewey's reticence to criticize his American contemporaries by name ought to be more seriously considered in the voluminous debate about Dewey's legacy. Before turning to that argument, however, I turn to Dewey's employment of the history of educational philosophy in his works.

\section{Dewey and the History of Educational Philosophy}

3 One hundred years after placing his educational aims alongside Plato, Rousseau and others in Democracy and Education, Dewey's analysis reads not as ambitious overreaching but as appropriate and fitting - Democracy and Education incontestably stands among the most important works of the history of educational thought. Yet Dewey did not regularly engage deeply the philosophers of the past in his educational writings. Unlike, say, Nietzsche, Heidegger, and Derrida, whose works engage a historical conversation routinely and substantively, Dewey's educational works are only occasionally peppered with analysis and comparison of historical ideas and concepts.

4 Nevertheless, Dewey repeatedly made the case for the value of history in contemporary educational theory and practice. Dewey not only read widely in the history of education and educational philosophy, he also saw the benefit of students doing so. For example, Dewey assembled a syllabus for a "History of Education" correspondence course through Columbia University's School of Liberal Arts and Sciences. On the syllabus, Dewey wrote that "teachers, parents and others interested in correct educational theory and practice" need to recognize that "no teacher can do the best possible with the present conditions and tendencies without knowing something of how they came to be" (LW 17: 160). ${ }^{2}$ The range of topics and readings in the syllabus are remarkably broad; the course covers, for example, Greek, Chinese, Roman, early Christian, Medieval, and Renaissance education, in addition to more recent history. On the Greeks alone the students were instructed to read not only selections from Plato and Aristotle but also selections from Protagoras, Isocrates, Aristophanes, Thucydides, and Homer. He directed students to historical scholarship on the sophists, but Dewey warns them that the authors he assigned to them (Paul Monroe and Thomas Davidson) exaggerate the individualistic nature of the sophists' work (LW 17: 183-4). ${ }^{3}$ Dewey's detailed syllabus (of which only the first four of twenty-four sections are extant) basically amounts to its own textbook; it is evidence of the depth of Dewey's awareness of and engagement with not only historical educational philosophy but also contemporary scholarship on the subject.

5 Yet Dewey's educational publications, despite occasional references to historical figures, do not generally explore historical philosophers' ideas at length. ${ }^{4}$ Dewey did not need to turn to history to find a wide variety of competing articulations of educational aims. He found himself in a particularly rich environment in the late nineteenth and early twentieth centuries in that regard: Dewey and his contemporaries were deeply immersed in debates about the purpose of schooling in America. It was a time in American history when more and more children were attending schools, and attending them for longer. 
The subsequent growth of schools led to much debate about what those schools ought to accomplish; should they prepare graduates for work, for college, or for "life"? Should they cultivate discipline, or develop students' interests? The list could go on - the chapter headings of Democracy and Education capture the wealth of educational aims debated while Dewey was writing. And, yet, at the key moment of argument in Democracy and Education is a critique of some of the giants of the western canon rather than his contemporaries. Why does Dewey turn to historical philosophers instead of his contemporaries' arguments?

\section{Plato, Rousseau, Fichte and Hegel in Democracy and Education}

In chapter seven, arguably the heart of Democracy and Education, Dewey made the case that "democracy is more than a form of government; it is primarily a mode of associated living, of conjoint communicated experience," and provided two standards for evaluating the quality of social life: "the extent in which the interests of a group are shared by all its members, and the fullness and freedom with which it interacts with other groups" (MW 9: 105). His conception of the relationship of democracy and education is presented in the first two sections of chapter seven (7.1 and 7.2). In a somewhat abrupt transition, he wrote,

subsequent chapters will be devoted to making explicit the implications of the democratic ideas in education. In the remaining portions of this chapter, we shall consider the educational theories which have been evolved in three epochs when the social import of education was especially conspicuous. (MW 9: 94)

7.3 focuses on Plato, 7.4 on Rousseau (primarily, at least, as the most prominent figure of "The 'Individualistic' Ideal of the Eighteenth Century") and 7.5 on Fichte and Hegel (as representatives of "Education as National and as Social").

Dewey wrote that Plato's educational philosophy is "in bondage to static ideals [...] the final end of life is fixed" (MW 9: 97). Further, Plato "limited his view to a "general and ultimate' aim," which Dewey warned, is something that "educators have to be on their guard against" (MW 9: 116). Dewey's critique, on the one hand, makes sense. Plato's Socrates does indeed discuss the value of understanding the ultimate aim of education establishing a just community under the wise leadership. And Plato's Socrates does indeed propose a society with three fixed classes. Yet there is something unsatisfactory in Dewey's analysis. Plato's Republic is not the only place one could find a society that is "in bondage to static ideals" nor is it necessarily the best example of that. Dewey knew well of class-based societies of the past and in 1916. Was Plato really the best source for this critique? Dewey ignores most of the innovations that Plato's Socrates describes that have become influential in educational philosophy and are of continued influence in higher education. There is no discussion of the broad liberal arts curriculum of The Republic's Book VII (521d-34e). He offers no discussion on the importance of gender equality in education, or the lasting effects on character of stories, music, and poetry. Perhaps most surprisingly given Dewey's task at hand, he neglects to address Socrates' critique of democracy in Book VIII (555b-566b). Dewey has not necessarily mischaracterized Socrates' argument, but the reader begins to wonder why Dewey would turn to Plato at such a critical point of Democracy and Education if his treatment of Plato is so partial. 
9 I shall discuss Dewey's analysis of Rousseau, Fichte, and Hegel below, but for now it suffices to say that Dewey's engagement with their ideas in Chapter 7 is also conspicuously limited. Indeed, among the copious scholarship on Democracy and Education since its publication one hundred years ago, very little scholarship has appeared on Dewey's treatment therein of Plato, Rousseau, Hegel, and Fichte. And this is fitting, since, as I'll argue, his engagement serves another purpose. So why did he address them at all, let alone put them at the very core of his book?

10 One obvious and incontestably valid reason is that Dewey believed that through critique of the ideas of others, he could more clearly articulate his own educational philosophy. Using Plato, Rousseau, and others to test out his two standards of democratic education is clearly central to Dewey's use of them. But since he spends most of Democracy and Education applying these standards in great depth to contemporary concerns, and does so quite successfully, the value of these historical philosophers in the book is questionable.

11 Another explanation might be that Dewey intended to place himself alongside Plato and Rousseau as one of the greatest educational philosophers in history. By 1916, Dewey was already hailed internationally as the leading educational theorist of his generation, so maybe he believed there to be value in distinguishing his own views from the other giants of educational thought. Dewey may have wanted to juxtapose his argument with theirs to illuminate the new, paradigm challenging directions he sought to take educational philosophy and society more generally.

12 As should be clear from my discussion of Dewey's history course, I do not believe that Dewey was either poorly informed about the history of educational philosophy, nor that he was uninterested in it. To the contrary, Dewey's "History of Education" syllabus suggests that he was eminently capable of providing a more robust critique of those historical philosophers should he have elected to do so. There is something else at play in chapter seven: Dewey used these historical accounts to critique his contemporaries' educational theories and practices.

13 In the two decades preceding the publication of Democracy and Education, and during the period that he was writing it, Dewey was immersed in thinking about and popularizing child-centered, progressive, experimental schools. Dewey's followers and critics often associated him with child-centered, pedagogical progressives, but this was an association he often resisted.

Dewey's criticism of Rousseau in Democracy and Education is targeted not only at Rousseau, and, I argue, not primarily at Rousseau. In chapter nine, Dewey explicitly wrote that nature as aim is "of recent influence" (MW 9: 118), appealing to the "educational reformers disgusted with the conventionality and artificiality of the scholastic methods," but that "since no one has stated in the doctrine both its truth and falsity better than Rousseau, we shall turn to him" (MW 9: 119). Dewey had long been warning of the excesses of child-centered, pedagogical progressivism. ${ }^{6}$ Democracy and Education was no exception as Dewey reiterated that, for example, the "idealizing of childhood" was in effect "nothing but lazy indulgence" (MW 9: 56). Dewey's criticism of pedagogical progressivism was not of merely theoretical problems that a progressive school might encounter; by 1916, in addition to the experiences with the progressive Colonel Francis Parker's school (which Dewey's children had attended: see Westbrook 1991: 96) and his own Laboratory School, Dewey was well aware of the pitfalls of the "new" education, and his knowledge of these schools informed his analysis in Democracy and Education. 
In Schools of To-Morrow, published in 1915, Dewey provided an account of several schools that endorsed Rousseauean ideals, ideals about which he would point out many flaws in Democracy and Education. Dewey and his daughter and co-author wrote that, of the various schools they described, "most of these points of similarity are found in the views advocated by Rousseau" (MW 8: 389). For example, of Mrs. Johnson at Fairhope, in Alabama, they noted that "her main underlying principle is Rousseau's central idea" about the nature of childhood (MW 8: 222). Dewey did not criticize these individuals or schools directly though, despite the fact that the schools are, in many ways, examples of the "new" education that he consistently described as extreme in My Pedagogic Creed, The Child and the Curriculum, and in other educational writings. Only Rousseau and, to a much lesser extent, the Italian educational theorist Maria Montessori are targets of any direct criticism in the Schools of To-Morrow. ${ }^{7}$

Rousseau stands in for the sorts of schools and teachers he described in Schools of ToMorrow. In Democracy and Education, Dewey criticized Rousseau because "merely to leave everything to nature was, after all, but to negate the very idea of education" (MW 9: 99). ${ }^{8}$ Such a clear, harsh attack is never leveled at Dewey's American contemporary pedagogical progressives by name, though "leaving things to nature" was very much an orienting ideal of the progressive schools that were being conceived of or opening in that period. ${ }^{9}$ Only in the conclusion of Schools of To-Morrow does Dewey note, in what might be read as a rebuke of the schools described, that "mere activity, if not directed toward some end, may result in developing muscular strength, but it can have very little effect on the mental development of the pupils" (MW 8: 391). Is the conclusion referring to schools reported on in the book, or to other schools which fall short of the examples reported on in the book? The reader is left to speculate about whether the schools described in Schools of To-Morrow somehow met the ideals of democratic schools that Dewey described in the conclusion. ${ }^{10}$ Nor in all of the reporting of the schools in Schools of To-Morrow, in which the joy, cheerfulness, and happiness of the children is a frequent theme,${ }^{11}$ does Dewey raise a concern that the emphasis on the individual might result in neglecting the social aspect of education. The criticism falls on Rousseau alone, and the "sentimental egotism" of his educational philosophy (MW 8: 249).

Maybe Dewey considered the American educators featured in Schools of To-Morrow unlike Montessori and Rousseau - too minor or too close to him to warrant rebuke from him; Dewey would have been well aware that his opinion on all matters educational was taken very seriously by the 1910s, and may therefore have been reluctant to judge harshly the educational pioneers he featured. But to better understand Dewey's reluctance to criticize pedagogical progressives, we might consider the case of William Heard Kilpatrick, who was arguably the most influential pedagogical progressive. Two years after the publication of Democracy and Education, Kilpatrick (1918) published "The Project Method," instantly launching him to the forefront of the charge to implement the "new" education in schools.

In the view of many scholars, Dewey labored tirelessly to distinguish himself from childcentered progressives. Westbrook, for example, writes that Dewey "took every available opportunity" (Westbrook 1991: 502) to challenge them, and that he was "anxious to distinguish his thinking from that of other reformers with whom he profoundly disagreed" (Ibid.: 501). Westbrook names Kilpatrick as "one of [Dewey's] principal targets" (Ibid.: 504). Yet the direct references to Kilpatrick in Dewey's Collected Works tend to be positive. Though scholars point to essays like "The Way Out of Our Educational 
Confusion" (LW 6: 75-89) as a direct attack on the project method, the work never mentions Kilpatrick by name. And Dewey's criticism in that essay could be read as directed not at the project method in principle, but rather at the way that the project method was implemented in some elementary schools. One searching Dewey's Collected Works for explicit, sustained critical engagement with Kilpatrick's ideas would find only the appreciative foreword Dewey penned for Kilpatrick's biography in 1952 (LW 17: 52-6). In Democracy and Education, readers encounter similar reluctance. Dewey challenged Rousseau because it enabled him to air, once again, his criticism of pedagogical progressivism. The effectiveness of Dewey's indirect criticism of pedagogical progressivism is something to which I shall return in the next section. First, we might recognize that Dewey's approach was similar when addressing the social efficiency progressives.

In his critique of German nationalistic ideals in 7.5, Dewey explicitly noted that social efficiency was emphasized as an aim of nationalistic education; in Germany,

the school system [...] supplied the patriotic citizen and soldier and the future state official and administrator and furnished the means for military, industrial, and political defense and expansion, it was impossible for theory not to emphasize the aim of social efficiency. (MW 9: 100; emphasis added)

Dewey's discussion of nineteenth century political and social aims in chapter seven (a line of argument he continued in chapter nine), allowed him to critique the administrative, social efficiency progressives indirectly. ${ }^{12}$

The social and national aims attributed to Fichte and Hegel in 7.5 diverged in two important ways among Dewey's contemporaries. On the one hand, some maintained the Hegelian framework for viewing individuals as needing to be civilized, in a sense, and brought into a national culture. The educational expression of this Hegelian view was the much debated (and much scorned by progressives) Committee of Ten Report of 1893 and the Committee of Fifteen Report of 1895. Charles W. Eliot and William Torrey Harris made an unapologetic case for a broad, liberal arts curriculum for all (rejecting the progressive calls for curricular differentiation). Dewey suggested in his analysis of national and social aims, as well as his discussion of culture as aim (in chapter nine, section three), that a rigid, common, liberal arts curriculum is yet another way that an individual student's interests are subordinated to an external end, in this case to initiate the student into culture.

On the other hand, social efficiency progressives like David Snedden argued that schools should prepare students for their civic, economic roles in the state. Social efficiency, in Dewey's analysis, subordinated the student to a civic goal. Dewey criticized social efficiency progressives for articulating a vision of education that would only perpetuate the status quo, even exacerbating social stratification in which different schools prepared students for a life similar to that of their parents' community:

It is the aim of progressive education to take part in correcting unfair privilege and unfair deprivation, not to perpetuate them [...] there is a danger that industrial education will be dominated by acceptance of the status quo. (MW 9:126)

Dewey wrote an essay criticizing vocational education in The New Republic in 1914 to which David Snedden responded. Dewey's rejoinder was published along with Snedden's critique in 1915 in the same magazine. In both essays, Dewey wrote that industrial, vocational education accepts the current class divisions and perpetuates them. In 1914 he wrote, 
every ground of public policy protests against any use of the public school system which takes for granted the perpetuity of the existing industrial regime, and whose inevitable effect is to perpetuate it, with all its antagonism of employer and employed, producer and consumer. ${ }^{13}$

1915, he wrote,

I am utterly opposed to giving the power of social predestination, by means of narrow trade-training, to any group of fallible men no matter how well-intentioned they may be. (MW 8: 411) $)^{14}$

In Democracy and Education, rather than targeting David Snedden directly for his efforts to determine students' aptitudes and, consequently, their civic and economic potential, Dewey wrote broadly of the problem of subordinating the individual to the state. Snedden's name appears nowhere in Democracy and Education, not even when Dewey turns again to the topic of social efficiency in chapter nine, nor when he explicitly addresses vocational aspects of education in chapter twenty-three.

Just as section 7.5 offers a subtle critique of two of Dewey's contemporaries' schools of thought, so too does the critique of Plato in 7.3. One might expect that Dewey would have been likely to criticize advocates of traditional education more directly. But despite Dewey's consistent, trenchant critiques of traditional education, he rarely targets specific individuals who promote or practice such pedagogy. ${ }^{15}$ In Plato, Dewey finds another stand in because, just as in the "old education," static knowledge serves as an end, and inflexibility and resistance to change are underlying principles (MW 9: 94 and 97). Additionally, perhaps the critique of Plato targets advocates of "culture as aim" such as William Torrey Harris, who thought that they could help the nation's youth escape from the cave, joining the ranks of the enlightened. Like Plato, Harris proposed a rigid, "academic" curriculum. At the same time, Dewey's concerns about class stratification targeted the social efficiency progressives because of the way their educational vision was centered on preparing students for particular kinds of employment, as I described above. In his discussion of vocational education in chapter twenty three, Dewey explicitly invoked Plato and described his most significant error as his "limited conception of the scope of vocations socially needed" (MW 9: 319).

Dewey's approach to the historical philosophers' ideas in chapter seven reveals that Dewey was not primarily concerned with illuminating the logic and nuances of those philosophers' arguments. Rather, Dewey highlighted in his analysis only the ideas that were influential, advocated, or debated among his contemporaries. And this treatment of historical philosophers is consistent with Dewey's general ideas about the value of history. "History," Dewey wrote, "deals with the past, but this past is the history of the present" (MW 9: 222). ${ }^{16}$ Indeed, Dewey's discussion of Plato, Rousseau, and the German Idealists ought to be read primarily as an engagement with the present - a vehicle to advance criticism of his contemporaries.

Connections between Dewey's historical critique and his contemporaries

\begin{tabular}{|l|l|}
\hline $\begin{array}{l}\text { Direct } \\
\text { Target }\end{array}$ & Indirect Target \\
\hline
\end{tabular}




\begin{tabular}{|l|l|}
\hline Plato & $\begin{array}{l}\text { Traditional education and “culture as aim" advocates who sought a fixed } \\
\text { curriculum and "static ideals" (e.g. William Torrey Harris) } \\
\text { Social efficiency progressives who sought to determine children's potential and } \\
\text { provide an education tailored to that potential (e.g., David Snedden) }\end{array}$ \\
\hline Rousseau & $\begin{array}{l}\text { Pedagogical, child-centered progressives (e.g. the educators featured in Schools of } \\
\text { To-Morrow) }\end{array}$ \\
\hline Fichte and & $\begin{array}{l}\text { Social efficiency progressives who subordinated the individual to serve the } \\
\text { state's industrial régime (e.g. David Snedden) } \\
\text { Hegelian defenders of traditional education who believed the state's role is to } \\
\text { civilize citizens, initiating them into national culture (e.g. William Torrey Harris) }\end{array}$ \\
\hline
\end{tabular}

\section{Dewey's Legacy} to support ideas and practices that were dramatically opposed to his intent. Scholars have proposed a variety of theories to explain this state of affairs. Some have argued that, early in his career, he advocated child-centered progressivism, and only later became its critic (most prominently in Experience and Education). ${ }^{17}$ But such an explanation is not supported by Dewey's works, since, from his earliest works, he warned against excessive indulgence of children's interests, and a variety of other beliefs and practices that characterized pedagogical progressivism. ${ }^{18}$ Another theory suggests that it was Dewey's disciples who molded Deweyan theory into practice, and Dewey's lofty, complex ideas were often simplified into practices that emphasized the "new" education, while failing to incorporate what Dewey argued was valuable about the "old" education. William Heard Kilpatrick is frequently identified as the culprit, and has been at least since the 1950s. ${ }^{19}$ Sometimes the argument of disciples' influence is proposed alongside an argument that Dewey was unclear about the practicalities of his theory or that he was difficult to read. ${ }^{20}$ Another explanation is that the middle road that Dewey sought to construct between the traditional and new curriculum led to his irrelevance to each side; Dewey's criticism of the traditional curriculum was too radical for most American educators to follow, and his failure to go as far as the pedagogical progressives failed to garner their support (Westbrook 1991: 508).

Other than the theory that Dewey changed course in his career, all of the other explanations for Dewey's legacy have merit. But one ought to consider whether Dewey's ideas would have been better understood if he had been willing to challenge the ideas of others more directly. Readers of Schools of To-Morrow and Democracy and Education can point to precise critiques of Montessori that not only better illuminate Montessori's theory, but also Dewey's. ${ }^{21}$ Had he been willing to subject his fellow Americans to similar direct criticism, Dewey's arguments would have been clearer, and Dewey would have been less easily mistaken for endorsing positions that he would have rejected. Among the clearest of Dewey's many discussions of vocational education, for example, is the essay he was invited to write to respond to Snedden's critique of him - in which, it is worth noting, Snedden read Dewey as "giving aid and comfort to the opponents of a broader, richer and more effective program of education" (Snedden 1915). Outside of a handful of responses

European Journal of Pragmatism and American Philosophy, VIII-1 | 2016 
similar to the one he penned to Snedden, or occasional book reviews, Dewey rarely criticized either his fellow progressives or his critics by name in his educational writings. ${ }^{22}$ The overall effect was to enable many of his readers to project views onto Dewey that Dewey would not have endorsed. Furthermore, it made it more difficult for Dewey's readers to grasp his precise challenge to the traditional education, social efficiency progressivism, pedagogical progressivism, and, later, social reconstructionism.

Why might Dewey have been so reluctant to criticize others? Dewey's work is animated by a deep respect for those teachers and researchers who were devoting their time and energy to pedagogy and educational reform. Perhaps the explanation is too facile, but Dewey may have hesitated to criticize the work of his fellow American pioneers who shared with him a commitment that education is central to the flourishing of a democratic society and democratic citizens. Dewey seems to have preferred to explore the ideas themselves of America's educational reformers, scholars, and teachers, rather than tarnish reputations. To put this in the most favorable light, Dewey's fellow educators and education scholars were treated with the generosity of spirit that Dewey believed ought to animate disagreements in the best kind of society.

Democracy and Education provides us with a prominent example of Dewey critiquing his contemporaries subtly and by analogy. By turning to Plato, Rousseau, Fichte and Hegel in chapter seven, Dewey's readers of the past one hundred years may have failed to appreciate how deeply his argument is rooted in the ideas and debates of his own lifetime. Yet Dewey's indirect approach also accounts for the creation of a work that genuinely warrants being called a classic - it rises above the educational debates of the early twentieth century to enter into a conversation with its educational ancestry, a conversation that Dewey propelled forward, giving Democracy and Education an air of timelessness.

\section{BIBLIOGRAPHY}

ANTLER J., (1987), Lucy Sprague Mitchell: The Making of a Modern Woman, New Haven, Yale University Press.

BEINEKE J. A., (1998), And There Were Giants in the Land: The Life of William Heard Kilpatrick, New York, P. Lang.

BURNETT J., (1979), “Whatever Happened to John Dewey?,” The Teachers College Record, 81, 2, 192-210.

CREMIN L. A., (1964), The Transformation of the School: Progressivism in American Education, 1876-1957, New York, Vintage Books.

DEWEY J., (1969-1991), The Collected Works, 1882-1953, edited by Boydston J. A., 37 vols., Carbondale and Edwardsville, IL, Southern Illinois University Press.

DEWEY J., (1991), The Collected Works of John Dewey: Index, 1882-1953, edited by Boydston J. A., Carbondale and Edwardsville, IL, Southern Illinois University Press. 
fallace T., \& V. FANTOZZI, (2013), “Was There Really a Social Efficiency Doctrine? The Uses and Abuses of an Idea in Educational History," Educational Researcher, 42, 3, 142-50.

JoHnston J. S., (2011), “The Dewey-Hutchins Debate: A Dispute over Moral Teleology,” Educational Theory, 61, 1, 1-16.

JONAS M. E., (2011), “Dewey's Conception of Interest and its Significance for Teacher Education," Educational Philosophy and Theory, 43, 2, 112-29.

KANDEL I. L., (1958), “A Controversy Ended,” The Educational Forum 22, 175-81.

KILPATRICK W., (1918), “The Project Method,” The Teachers College Record, 19, 4, 319-35.

KIRBY C. C., (ed.), (2014), Dewey and the Ancients: Essays on Hellenic and Hellenistic Themes in the Philosophy of John Dewey, London, Bloomsbury.

KLIEBARD H. M., (2002), Changing Course: American Curriculum Reform in the 20th Century, New York, Teachers College Press.

LABAREE D., (2011), "How Dewey Lost: The Victory of David Snedden and Social Efficiency in the Reform of American Education," in Tröhler D., Schlag T., \& Ostervalder F., (eds.), Pragmatism and Modernities, Rotterdam, Sense Publishers.

NULL J. W., (2007), Peerless Educator: The Life and Work of Isaac Leon Kandel, New York, Peter Lang. Plato, (2000), The Republic, edited by G. R. F. Ferrari, trans. Tom Griffith, Cambridge \& New York, Cambridge University Press.

SNEDDEN D., (1915), “Vocational Education,” The New Republic, May 15, 1915.

WAKS L. J., (2007), “Rereading Democracy and Education Today: John Dewey on Globalization, Multiculturalism, and Democratic Education," Education and Culture, 23, 1, 27-37.

WESTBROoK R. B., (1991), John Dewey and American Democracy, Ithaca, NY, Cornell University Press.

\section{NOTES}

1. In a 1916 letter he wrote " $[\mathrm{t}] \mathrm{he}$ Democracy and Education in spite of its title is the closest attempt I have made to sum up my entire philosophical position." In 1930 he wrote that it was "for many years [the book] in which my philosophy, such as it is, was most fully expounded." Both letters are cited in MW 9: 377. References to John Dewey's published works are to the critical edition, The Collected Works of John Dewey, 1882-1953, edited by Boydston J. A., Carbondale and Edwardsville, Southern Illinois University Press, 1967-1991, and published in three series as The Early Works 1882-1899 [EW], The Middle Works 1899-1924 [MW], and The Later Works 1925-1953 [LW].

2. Dewey was consistent in his remarks about the value of history, at least, if history is understood in a certain way (a topic to which I return below). For another example of Dewey attesting to the value of history, see MW 1: 104-9.

3. On the depth of Dewey's engagement with the Greeks in particular, see Kirby 2014.

4. In contrast, throughout his philosophical works on subjects other than education, readers encounter frequent discursions on Aristotle, Plato, Hume, Kant, and so forth. Consider the case of Aristotle, for example. The index to Dewey's Collected Works contains 160 lines of references to Aristotle. Yet only two of the 160 lines of entries refer specifically to Aristotle on education, referring readers to three works, two of them encyclopedia entries (in MW 7 and MW 13, respectively). The other reference is to Democracy and Education in the "Labor and Leisure" 
chapter. There are a few other references to Aristotle on education that appear under more specific Aristotle index items - in Democracy and Education, for example, Aristotle is also mentioned in the "Intellectual and Practical Studies," the "Physical and Social studies" and the "Theory of Morals" chapters. Nevertheless, these references add at most a few more lines to the two others on education, and remain a very slim proportion of the 160 lines of entries overall in Dewey's Collected Works. Given how often Dewey discussed Aristotle in his non-educational philosophical writings, the contrast is striking. See Dewey (1991: 116-8).

5. Part of the unnaturalness in the transition in the argument may have been due to the fact that the book was originally contracted as a textbook. Indeed the initial contract assigned the title of "Text-book on the Philosophy of Education" (MW 9: 377-8).

6. In My Pedagogic Creed, he wrote that a student's interest is not to be "repressed," but, pointedly, it must not be "humored" either (EW 5: 92-3). In "Interest in Relation to training of the Will," published in 1896, he wrote that "[t]he spoiled child who does only what he likes is the inevitable outcome of the theory of interest in education" (EW 5: 116). In 1902, in The Child and the Curriculum, Dewey rejected the "sentimental idealizations" of the child (MW 2: 279). In Interest and Effort in Education published in 1913 his tone is similar (MW 7: 154-5). This is not to say that Dewey did not continuously refine his position. He certainly did so. See, for example, his evolving treatment of interest in Jonas (2011: 124-6).

7. The criticism of Montessori schools was minimal, but the fact that the Montessori schools received any criticism at all, given the treatment of the other schools in the book, is noteworthy. The Deweys praise Montessori schools because the student "is confronted with an obvious problem, which is solved by his own handling of the material. The child is educating himself in that he sees his own mistakes and corrects them, and the finished result is perfect; partial success or failure is not possible." But the Deweys argued that Montessori students are not free intellectually because they lack the freedom to create (MW 8: 307, 309). Notably, Montessori is also criticized in Democracy and Education (MW 9: 160 and 205). One can only speculate about why Dewey was willing to criticize Montessori by name. Perhaps it was because her schools were so well established in Italy that he did not fear for her reputation. As the schools were growing in popularity beyond Italy, maybe Dewey thought that American progressive educators might correct some of the problematic aspects of them. Or perhaps Dewey was contributing to a scholarly discussion taking place among his colleagues at Teachers College. William Heard Kilpatrick had travelled to Italy during the time Dewey was writing Schools of To-Morrow and Democracy and Education and had reported on Montessori's educational theory and influence. Kilpatrick published The Montessori System Examined in 1914 and acknowledged Dewey's suggestions on his draft version of the book. See Beineke (1998: 71).

8. Dewey was not beyond character attacks on Rousseau. In the opening of chapter four of Schools of To-Morrow, Dewey pointed out to readers that Rousseau had abandoned his children to the foundling system (MW 8: 248).

9. By the 1920s, many schools would be caricatured for their laissez-faire approach, including that of Lucy Sprague Mitchell, with whom Dewey was a close associate. Cremin describes places like Caroline Pratt's Play School (opened in 1913 and which Lucy Sprague Mitchell began supporting and working in by 1916) as follows: "In too many classrooms license began to pass for liberty, planlessness for spontaneity, recalcitrance for individuality, obfuscation for art, and chaos for education - all justified in the rhetoric of expressionism" (Cremin 1964: 207). Lucy Sprague Mitchell, like other pedagogical progressives, is never the direct target of Dewey's criticism, despite the fact that, in many ways, her school was an extreme example of the "new" education. On Sprague and Dewey's relationship, see Antler (1987: ch. 11).

10. After its publication, he was quick to deny that the schools described in Schools of To-Morrow were "Dewey" schools, inspired by his work. Rather, he wrote in an open letter addressed to William Bagley, "much of the significance of the various experiments lies in the fact that they 
have sprung up independently under diverse auspices" (MW 8: 414). Further, Dewey seems to have conceived of the book as a purely journalistic work, a work in which, perhaps, his criticism was not appropriate (MW 8: 388). On this point, see Kliebard (2002: 94-6). But Dewey's reluctance to criticize directly progressive experimental schools and educators in Schools of To-Morrow, as I shall show, is a general feature of his treatment of pedagogical progressives, and not limited to that work. Further, he did indeed offer some generalized criticism of the new education in the conclusion of the work, and via Rousseau, as I describe below.

11. For example: "They are uniformly happy in school, and enthusiastically proclaim their 'love' for it. Not only is the work interesting to the group as a whole, but no individual child is forced to a task that does not appeal; each pupil may do as he pleases as long as he does not interfere with anyone else" (MW 8: 226).

12. I speak broadly about social efficiency progressivism, though it is an "amorphous, if not ambiguous" category (Fallace \& Fantozzi 2013: 145).

13. Dewey noted that the defenders of vocational education often cited Germany as a model. Dewey warned that Germany's purpose was "frankly nationalistic [...] the wellbeing of the state as a moral entity is supreme. The promotion of commerce against international competitors is one of the chief means of fostering the state" (MW 7: 94-5).

14. Dewey also wrote in that article that "[t]he kind of vocational education in which I am interested is not one which will 'adapt' workers to the existing industrial regime; I am not sufficiently in love with the regime for that. It seems to me that the business of all who would not be educational timeservers is to resist every move in this direction, and to strive for a kind of vocational education which will first alter the existing industrial system, and ultimately transform it" (MW 8: 412). In Democracy and Education he warned similarly of the danger of social predestination: "Any scheme for vocational education which takes its point of departure from the industrial regime that now exists; is likely to assume and to perpetuate its divisions and weaknesses, and thus to become an instrument in accomplishing the feudal dogma of social predestination" (MW 9: 328). See also his similar comments years later in LW 3: 262. On the debate with Snedden, see Labaree 2011.

15. Two decades after writing Democracy and Education, Dewey would pen two essays in The Social Frontier critiquing Robert Hutchins's The Higher Learning in America "Rationality in Education" (1936) and "President Hutchins' Proposals to Remake Higher Education" (1937). Despite all the attention to Dewey's direct challenge to Hutchins, those essays total only eleven pages in the Collected Works (LW 11: 397-407). The Collected Works Index lists only two other essays in which Hutchins is mentioned explicitly: "The Democratic Faith and Education" (1944) and "Challenge to Liberal Thought" (1944) in LW 15: 251-75. This is not to say that Dewey does not take up the debate with Hutchins elsewhere. It is merely to say that elsewhere he took up the debate indirectly, akin to his approach in Democracy and Education. At least Dewey's challenge to Hutchins, unlike his treatment of Kilpatrick, helped his readers understand the precise nature of their disagreement (though Dewey's argument is typically complex); see Johnston 2011.

16. Likewise he wrote: "A knowledge of the past and its heritage is of great significance when it enters into the present, but not otherwise" (MW 9: 81). On the nature of Dewey's engagement with the present in Democracy and Education in the context of the First World War, see Waks 2007. 17. Cremin offers a nuanced version of this position: "[A]s the twenties progressed, he became less the interpreter and synthesizer of the progressive education movement, and increasingly its critic" (Cremin 1964: 234).

18. In addition to my above discussion of the critique of Rousseau, see note 6 .

19. See Kandel 1958. See also Null 2007. Another related but distinct claim is that Dewey's pragmatic progressivism in education arose only after Rousseauean romantic progressive education had become well-entrenched. The romantic progressives adopted some of Dewey's critique of traditional education, but were never heavily influenced by Dewey. See Burnett 1979 . 
20. E.g. Cremin (1964: 238-9). H. L. Mencken wrote that Dewey "is the worst writer ever heard of in America, and probably the worst philosopher known to history" cited in Westbrook (1991: $501)$.

21. See note 7.

22. On the Robert Hutchins exception, see note 15.

\section{ABSTRACTS}

In Democracy and Education, in the midst of the pivotal chapter on "The Democratic Conception in Education," Dewey juxtaposes his educational aims with those of Plato, Rousseau, Fichte and Hegel. Perhaps Dewey believed that an account of their views would help elucidate his own, or he intended to suggest that his own ideas rivaled or bested theirs. I argue that Dewey's discussion of historical philosophers' aims of education was also designed to critique his contemporaries subtly and by analogy. My analysis of Dewey's critique supports a second argument: one of the reasons Dewey's legacy has been long debated (particularly his relationship to pedagogical progressivism) derives from his reluctance to criticize his contemporaries explicitly and directly. Had Dewey critiqued his fellow American progressives in the same way he did historical European philosophers of the past, his readers would have better understood his relationship to progressive American educational ideas and practices. Yet Dewey's subtle approach also accounts for the creation of a work that genuinely warrants being called a classic - it rises above the educational debates of the early twentieth century to enter into a conversation with its educational ancestry, a conversation that Dewey propelled forward.

\section{AUTHOR}

\section{AVI I. MINTZ}

The University of Tulsa

avi-mintz[at]utulsa.edu 